\title{
A REGRA DE OURO COMO LIMITE CONSTITUCIONAL AO ENDIVIDAMENTO PÚBLICO NO BRASIL
}

\author{
Francisco Gilney Bezerra de Carvalho Ferreira \\ Doutorando em Direito Financeiro (USP). \\ Mestre em Direito (UFSC/SC). MBA em Gestão Pública (FGV). \\ Especialista em Direito Público (UniProjeção/DF). \\ Procurador Federal (AGU) e Professor de Direito \\ Constitucional e Financeiro.
}

\section{SUMÁRIO}

Introdução - 1. A dívida pública no contexto da atividade financeira estatal -2 . A regra de ouro brasileira e sua disciplina normativa -3 . O debate sobre a relativização da regra de ouro no Brasil - 4. Dívida pública e regra de ouro: a vedação ao retrocesso - Considerações finais - Referências. 


\section{INTRODUÇÃO}

Não é de hoje que o tema da dívida pública e sua gestão suscita intensos debates e ingressa na ordem do dia. $\mathrm{O}$ endividamento persiste, sendo um dos problemas cruciais para a administração das finanças públicas no Brasil. Apesar dos avanços perceptíveis na legislação pátria em matéria de regulação da dívida e a nova cultura de responsabilidade fiscal que tem germinado em tempos recentes, tem-se observado a paradoxal convivência de instrumentos de controle com elevados déficits correntes e um endividamento crescente. A dívida pública, que, em essência, constitui-se em peça fundamental ao Estado e fonte de potencial incremento do patrimônio público, fragiliza-se em suas premissas fundantes. Os efeitos negativos geralmente são associados à existência da dívida, porém, não se constituem em gravames inerentes à própria natureza do instituto, senão à deficiente gestão que historicamente dela tem sido feita.

A delimitação do presente tema resulta da observação de que a problemática ingressa no meio social revestida de importância singular, tornando-se imperiosa a análise responsável quanto ao endividamento público e seus limites. A rigor, o controle da dívida pública decorre da própria necessidade de preservar os princípios que sustentam a sua legitimação. Dentre os limites existentes no ordenamento pátrio, destaca-se a Regra de Ouro (art. 167, III, CF/88), para a qual se direciona o presente exame, sobretudo considerando a discussão que se renova diante das projeções negativas para o seu cumprimento. Nos últimos anos, de fato, apesar de formalmente respeitada, passou-se a observar expressiva deterioração na margem de recursos para o atendimento da Regra de Ouro, de onde surge o argumento, quase sempre desvinculado do exame qualitativo da dívida, voltado à atenuação da norma.

É nesse panorama que se buscará desenvolver a presente abordagem. De início, serão expostos os conceitos preliminares para o entendimento do tema e se verificará a real função da dívida pública no contexto da atividade financeira estatal. Na sequência, será evidenciada a disciplina normativa da Regra de Ouro no Brasil em seus pontos principais de discussão, em conjunto com a percepção sobre os eventuais entraves que a fragilizam. Adiante, enfrenta-se o debate a respeito dos limites ao endividamento previstos na referida norma, tendo por base a apresentação de dados que apontam para a iminente incapacidade de seu atendimento nos exercícios vindouros. Ao final, invoca-se a necessidade não só de refletir sobre o montante da dívida, mas a avaliação passa obrigatoriamente pelo reforço às premissas de responsabilização fiscal e endividamento sustentável, evitando-se o descontrole das contas públicas. Quanto aos aspectos metodológicos, o desenvolvimento da investigação se alinha à técnica de pesquisa bibliográfica, com método de abordagem crítico-indutiva e avaliação de dados qualitativa. 


\section{A DÍVIDA PÚBLICA NO CONTEXTO DA ATIVIDADE FINANCEIRA ESTATAL}

$\mathrm{Na}$ busca pela consecução de seus fins, em especial a garantia do bem-estar comum e o regular funcionamento da sociedade, tornou-se incumbência do Estado, enquanto instituição político-social de modulação da coexistência humana, a permanente busca pelo atendimento das inúmeras necessidades públicas ${ }^{1}$, de onde surge, no exercício desse mister, o consequente desenvolvimento da atividade financeira estatal ${ }^{2}$. É nesse desiderato que se torna imperiosa a obtenção de recursos financeiros ${ }^{3}$, com os quais o Estado passa a se valer para honrar os compromissos constitucionais democraticamente firmados ${ }^{4}$. Tais recursos, normalmente, são provenientes do próprio incremento patrimonial estatal ou decorrentes dos cidadãos pela via tributária, mas nem sempre se mostram suficientes para responder integralmente aos anseios financeiros do Estado na mesma velocidade com que se fazem prementes, sendo necessário, não raro, recorrer a empréstimos perante terceiros, daí surgindo a opção pelo endividamento, quando oportuno ou inevitável no escopo de atuação estatal. Tem-se, assim, resultante do crédito público, a precisa noção de dívida pública como fonte alternativa de financiamento estatal para a realização das despesas que lhe são inerentes.

Em síntese, pode-se compreender a dívida pública como o conjunto de obrigações que decorre das operações de crédito em que o Estado obtém recursos financeiros por meio de empréstimos, com a promessa de pagamento futuro do principal acrescido de juros. Do outro lado da relação contratual, tem-se um terceiro que disponibiliza recursos ao Estado em troca da remuneração (juros) que essa operação tende a proporcionar no tempo. Desse modo, seja por meio de

1 Regis Fernandes de Oliveira define necessidades públicas como "tudo aquilo que incumbe ao Estado prover em decorrência de uma decisão política inserida em norma jurídica” (OLIVEIRA, 2015, p. 179). E, ainda, Luigi Einaudi vê na satisfação delas a própria missão da economia política. Para leitura, cf. EINAUDI, 1948.

2 Sobre a atividade financeira estatal, vale notar: "Cuando el Estado y los demás entes públicos obtienen y utilizam médios dinerarios para realizar las tareas que la colectividad Le encomenda están desarrollando uma actividad que tradicionalmente se conoce com el nobre de actividad financeira" (LAPATZA, 2010, p. 139).

3 Se esta atribuição antes se ligava à requisição ou apossamento de bens, hoje o Estado substituiu tais processos por uma atividade financeira que visa à consecução das necessidades primárias (HARADA, 1995, p. 31-32).

4 J. J. Gomes Canotilho explica que numa sociedade plural e complexa, a constituição é um produto do pacto entre forças colidentes, resultando em vários "compromissos constitucionais" (CANOTILHO, 2003, p. 218). 
contratos em que o governo capta recursos de instituições financeiras, ou ainda, seja mediante obtenção de dinheiro com a venda de títulos ao público, chama-se de dívida pública o montante das obrigações assumidas pelo Poder Público em decorrência do recebimento de recursos a título de empréstimo público com o dever futuro de restituição ${ }^{5}$.

A rigor, toda dívida pública nasce de um pressuposto que lhe precede: o crédito público ${ }^{6}$. Embora seja comum a utilização em vários sentidos da noção de crédito público e nem sempre eles guardem a necessária tecnicidade, a percepção mais acurada nos revela que se trata de instituto relacionado, em essência, à confiança de que goza o ente estatal para contrair empréstimos junto a terceiros. Ao falar em crédito público, está-se, pois, diante de uma oferta de credibilidade, em especial a que o titular dos recursos confere àquele que os empresta. A própria origem etimológica da palavra "crédito" deriva do latim credere, que significa crer, confiar, acreditar. O conceito de crédito público, portanto, tem por elemento constitutivo fundamental a confiança ${ }^{7}$, base na qual se sustenta e de onde se extrai a ideia de que a utilização desse mecanismo importa, desde a sua concepção, o ingresso na importante discussão quanto à capacidade de solvência do Estado e os limites para a realização de tais operações, porquanto do crédito nasce a futura dívida a ser adimplida.

A verdade é que ainda há certa confusão terminológica, muitas vezes causada pela própria legislação aplicável, no que diz respeito ao alcance e significado de conceitos que se encontram inevitavelmente interligados (dívida pública, crédito público, operação de crédito, empréstimo público), mas que possuem delimita-

5 Nesse sentido: “A dívida pública propriamente dita representa o somatório das obrigações do Estado perante todos os seus credores referentes aos empréstimos públicos contraídos no mercado interno ou externo, seja através de contratos diretos com instituições financeiras ou demais credores, seja pela emissão de títulos, para financiar as despesas públicas não cobertas pelas receitas públicas ordinárias” (ABRAHAM, 2017a, p. 194).

6 Na visão de João Ricardo Catarino, importa notar: "O Crédito Público é o conjunto de operações levadas a efeito pelo Estado tendo em vista a obtenção de meios de liquidez (empréstimo público) para a satisfação de responsabilidades financeiras. Ele pode, assim, ser visto de duas formas: enquanto instituição pública e enquanto instrumento financeiro. Esta última denomina o conjunto de operações de endividamento e de gestão da dívida pública levados a efeito pelo Estado com a finalidade de obter os meios de liquidez necessários para a cobertura das suas necessidades e responsabilidades" (CATARINO, 2012, p. 140).

7 Heleno Taveira Torres identifica nos negócios caracterizadores de operações de crédito sempre a presença de três elementos constitutivos básicos, a saber: (i) confiança; (ii) capital; e (iii) tempo (TORRES, 2014, p. 448). 
ção perceptível ${ }^{8}$. Em suma, pode-se dizer que crédito público é a confiança de que goza o ente estatal para contrair empréstimo, o qual, por sua vez, refere-se ao contrato que instrumentaliza a operação de crédito da qual se beneficia o Estado a partir de uma transferência de liquidez, daí fazendo surgir a dívida pública, instituto que simboliza a obrigação decorrente do conjunto de compromissos em relação aos quais o Estado se onerou em virtude dos empréstimos públicos, competindo-lhe o ulterior encargo de reembolso do montante devido acrescido da remuneração do capital transferido. Logo, tem-se um ciclo que se desenvolve em cadeia: o endividamento nasce do crédito (base de confiança), instrumentaliza-se no empréstimo (modalidade de operação de crédito) e consubstancia-se na obrigação estatal de pagamento futuro (dívida pública) ${ }^{9}$.

A natureza jurídica dos empréstimos públicos, dos quais resultam a dívida para o Estado, é controversa na doutrina, levantando-se a discussão sobre considerá-los ato de soberania ou instrumentos de índole contratual ${ }^{10}$. Atualmente, porém, não há dúvidas de que a acepção mais acertada percebe nos empréstimos públicos a sua natureza contratual, inserida em regime de direito público. E, conforme às modalidades desses acordos bilaterais decorrem também as diferentes espécies de dívida pública: (i) quanto ao ente federativo contratante (dívida pública federal, estadual ou municipal); (ii) quanto ao local da celebração, pagamento ou execução do contrato (dívida pública interna ou externa); (iii) quanto ao prazo de duração contratual e restituição do pagamento (dívida pública flutuante ou consolidada $)^{11}$.

Independentemente de qual seja a espécie, a dívida pública possui relevantíssimas funções para a sociedade enquanto fonte alternativa de financiamento do Estado. Importantes efeitos podem justificar o endividamento público, na medida

8 Esclarecendo as expressões correlatas que envolvem o crédito público, cf. ASSONI FILHO, 2007, p. 20-22.

9 A propósito, explicita o tema Héctor Villegas: “(...) credito publico es la aptitud politica, econdmica, juridica y moral de un Estado para obtener dinero o bienes en prestamo; el empristito es la operación crediticia concreta mediante la cual el Estado obtiene dicho prestamo, y la deuda publica consiste en la obligación que contrae el Estado con los prestamistas como consecuencia del emprestito" (VILLEGAS, 2001, p. 759).

${ }^{10}$ Em visão abrangente das teses sobre a natureza dos empréstimos públicos, cf. FONROUGE, 2011, p. 1559 e ss.

11 Os empréstimos costumam ainda ser classificados como voluntários ou forçados. Estes últimos, são tributos (empréstimos compulsórios), não integram a noção de empréstimo decorrente do crédito. Na lição de Geraldo Ataliba, é preciso que o nascimento da obrigação seja determinado pela livre manifestação de vontade do credor, só assim havendo a contratualidade que confere qualidade de empréstimo (ATALIBA, 1973, p. 26). 
em que, por meio dele, podem-se alcançar a alavancagem nos investimentos, o aquecimento da economia em períodos de retração, além do possível controle inflacionário e o compartilhamento dos encargos entre gerações, entre outros benefícios encontrados em favor desse poderoso instrumento de injeção de recursos. Tal destaque é salutar para que se refute, desde logo, a mera defesa do recrudescimento dos limites para a dívida pública sem antes entendê-la como um auxiliar de vultoso alcance para o Estado, quando empregada, todavia, com prudência e cautela. O controle do endividamento público, a rigor, decorre da própria necessidade de preservar a sua vocação original.

Costuma-se falar, apesar de ser árdua a noção da origem dos empréstimos públicos, que sua primitiva utilização teve início ainda na Antiguidade e na Idade Média $^{12}$, fase histórica em que a dívida pública, além de guardar forte vínculo com o governante ante a confusão à época entre o patrimônio deste e o tesouro do governo, não se direcionava propriamente à cobertura de serviços públicos, destinando-se mais ao financiamento das guerras. Somente adiante, com o capitalismo e a expansão do fluxo de riquezas, na esteira do Estado moderno, surgiu a real necessidade de financiamentos e da evolução dos mecanismos financeiros. Inicialmente, porém, desvinculado das reivindicações de cunho social, o Estado Fiscal que emergia $^{13}$, diante das revoluções liberais do século XVIII, tinha por característica forte o absenteísmo estatal. Mas a liberalidade desregulada do capital privado e o advento de desigualdades sociais, associadas à crise financeira de 1930, levaram posteriormente a um certo esgotamento das ideias liberais e à consequente renovação estatal pela inevitabilidade de sua maior intervenção na sociedade.

O Estado, enfim, cede espaço à doutrina do Bem-Estar Social (Welfare State $)^{14}$, com gradual ampliação das prestações públicas, sobretudo na área dos incentivos fiscais, subsídios e investimentos públicos. As funções assumidas na missão de provedor social conduziram o Estado a um incremento de sua atividade financeira em busca por novas fontes de recursos. Sob a influência de Keynes ${ }^{15}$,

12 Em refinado relato acerca dos empréstimos públicos desde a Antiguidade, cf. BALEEIRO, 1997, p. 460 e ss.

13 Ricardo Lobo Torres ensina que nesse momento o chamado Estado Fiscal se restringia ao exercício do poder de polícia, a administração da justiça e a prestação de poucos serviços públicos, fornecendo os recursos para atender às necessidades mínimas da garantia estatal às liberdades individuais (TORRES, 2008, p. 11).

14 Sobre a superação do Estado Liberal pelo Estado Social, cf. BONAVIDES, 2013.

15 A teoria econômica de Keynes recomendava orçamentos deficitários em épocas de recessão, incentivando a intervenção estatal por via de uma política de gastos públicos. Para aprofundamento, cf. KEYNES, 1951. 
passou-se a admitir orçamentos deficitários ou anticíclicos para financiar direitos sociais e combater as crises do capitalismo ${ }^{16}$. As políticas redistributivas foram se afirmando progressivamente, mas o excesso de endividamento público, o aumento potencial dos gastos e a elevada carga tributária ${ }^{17}$ resultaram em um insustentável descontrole das finanças públicas e no posterior colapso do Estado do Bem-Estar Social, deslegitimando-se a sua real mantença. Daí em diante, tornou-se indispensável a reavaliação do papel do Estado ante as sérias contestações pelas quais passava, refreando-se a teoria keynesiana com o retorno à busca pelo equilíbrio das contas públicas e a maior moderação dos gastos.

De certo modo, pode-se afirmar que o Brasil, embora sentindo esses efeitos de forma diferida, acompanhou o movimento de expansão e retração do modelo de intervencionismo estatal, tendo-se observado um crescimento acelerado nas despesas públicas especialmente a partir do término da Segunda Guerra Mundial, com o despontar atual para uma tendência de limitação dos gastos e busca pelo controle do endividamento público, eixo de preocupação econômica da maioria das nações ocidentais na segunda metade do século XX. Na realidade pátria, registra-se a origem da dívida brasileira ainda no período colonial, desde os séculos XVI e XVII, com a realização de empréstimos por governadores da Colônia, tendo o país iniciado a sua vida política, em alguma medida, já imerso em dívidas ${ }^{18}$. A real inquietação por maiores limites para o endividamento, contudo, veio em tempos recentes, em especial ao final dos anos 1980 do século anterior, em decorrência do patamar altíssimo que atingiu a dívida no regime de ditadura militar implementado em 1964. A necessidade crescente de investimentos e serviços públicos, de um lado, e a insuficiência de receitas públicas primárias para subsidiá-los, de outro, levaram o Brasil a recorrer ao crédito público, ocasionando ao longo do tempo um descontrole galopante das finanças e o comprome-

${ }^{16}$ James Giocomoni afirma que as concepções keynesianas foram amplamente empregadas quando boa parte dos países buscava sair da Grande Depressão de 1930. O sucesso dessas teorias resultou na universalização do intervencionismo estatal nos anos pós-guerra e nas décadas de 1950 e 1960 (GIACOMONI, 2017, p. 80).

17 Ressalta-se a influente crítica liberal proferida por James Buchanan, invocando Hobbes (Leviatã, de 1651), ao afirmar que a excessiva intervenção estatal na economia resultaria na aniquilação da liberdade, a pretexto do financiamento dos serviços públicos com a elevada carga de tributos. Para leitura, cf. BUCHANAN, 1975.

18 Para visão da história da dívida pública no Brasil, cf. SILVA; CARVALHO; MEDEIROS, 2009. A relevante obra estuda a experiência da dívida pública brasileira, em resgate de cada período histórico (Colônia, Império e República). Outras referências de destaque, em especial a origem da dívida externa, cf. BOUÇAS, 1950. 
timento da capacidade de solvência ${ }^{19}$. A falência do modelo brasileiro resultou também no significativo aumento de recursos captados junto a instituições internacionais, como o Fundo Monetário Internacional (FMI), e outras ${ }^{20}$.

Nesse contexto, o Estado brasileiro viu rapidamente crescer, de modo implacável, a imprescindibilidade de reformas fiscais para o combate ao endividamento público, incluindo instrumentos mais rígidos de controle dos gastos, seguindo a tendência global de busca pelo almejado equilíbrio fiscal ${ }^{21}$. Importante passo foi dado com a redemocratização ocorrida sob a égide da Constituição de 1988 e a expansão do Poder Legislativo em matéria financeira, sobretudo no que tange à disciplina do crédito público, incluindo a previsão de dispositivos que tentam conferir certa blindagem à atuação perdulária do Estado. No desenho constituinte de delimitação ao exercício do poder financeiro, coube precipuamente ao Congresso Nacional a competência para dispor sobre as operações de crédito e a dívida pública (art. 48, II, CF/88), bem como sobre o montante da dívida pública mobiliária federal (art. 48, XIV, CF/88).

Por seu turno, ao Senado Federal ficou reservado autorizar as operações externas de natureza financeira (art. 52, V, CF/88) e fixar os limites globais para o montante da dívida consolidada da União, dos Estados, do Distrito Federal e dos Municípios (art. 52, VI, CF/88), bem como dispor sobre limites globais e condições para as operações de crédito externo e interno de todos os entes federados, de suas autarquias e demais entidades controladas pelo Poder Público federal (art. 52, VII, CF/88), além de regular os limites e condições para a concessão de garantia da União em operações de crédito externo e interno (art. 52, VIII, CF/88),

19 Lembra Marcus Abraham que somado ao alarmante cenário do endividamento público pairava um descrédito evidente com a gestão pública em nosso país, predominando por muito tempo a despreocupação com gastos públicos, sistematicamente realizados sem considerar limitações de receitas (ABRAHAM, 2017b, p. 31).

20 Os números alarmantes são bem narrados por Regis Fernandes de Oliveira: "Com efeito, durante o Regime Militar (1964 em diante), a dívida cresceu para cerca de cem bilhões de dólares (US\$ 100 bilhões). Houve a Resolução 63/1967, do Banco Central que, ilusoriamente, permitia obtenção de empréstimos a juros supostamente baixos. Por muito tempo, a dívida aumentou brutalmente. Chegou a R \$ 1.480.000.000.000,00 (um trilhão e quatrocentos e oitenta milhões) o total da dívida interna e externa" (OLIVEIRA, 2015, p. 982).

${ }^{21}$ Fábio Gambiagi afirma que as regras fiscais se fortaleceram internacionalmente ao longo dos anos 90, entre outras razões, com a redução do déficit americano após a Lei Gramm-Rudman-Hollings, e a diminuição dos desequilíbrios fiscais nas economias europeias com o Tratado de Maastricht (GAMBIAGI, 2001, p. 79-80). Recentemente, como destacam Siegfried Bender e Raí Chicoli, o tema se intensificou em especial na crise de 2008 com países em altos níveis de endividamento em percentual do PIB (CHICOLI; BENDER, 2015, p. 1). 
e ainda, estabelecer limites globais e condições para o montante da dívida mobiliária dos Estados, do Distrito Federal e dos Municípios (art. 52, IX, CF/88) 22 .

Se, por um lado, a partir de tais normas inseridas pelo constituinte de 1988, pode-se inferir que a autorização legal para contratar é característica inarredável do crédito público, vinculando-se ele obrigatoriamente aos limites da disposição legislativa, por outro lado, ao se pensar em um sistema no qual fica atribuído ao Legislativo regular o controle dos gastos e do endividamento público, idealiza-se, pois, uma dinâmica de compartilhamento entre Governo e Parlamento ${ }^{23}$, de modo que a dívida pública não supere limites insuportáveis, desde logo se percebendo que a busca pelo endividamento sustentável é marca do nosso sistema atual. Essa característica consolida-se definitivamente com o advento da Lei Complementar n. 101/2000, a chamada Lei de Responsabilidade Fiscal ${ }^{24}$, normativo de crucial importância que estabelece, em especial no Capítulo VII ("Da Dívida e do Endividamento"), as normas gerais sobre o crédito público, os limites da dívida pública e das operações de crédito, a contratação das operações de crédito, as garantias e contragarantias, entre outras disposições ${ }^{25}$.

O pano de fundo da disciplina jurídica do endividamento público, portanto, encontra-se no ideal de prevenir desvios capazes de afetar o equilíbrio das contas públicas, com o nítido objetivo de preservar a função de financiamento alternativo estatal sem desbordar de limites que assegurem a dívida em níveis prudentes. Tal encargo cristaliza a obrigação estatal de agir com esmero na gestão das finanças, como variante que decorre do direito fundamental à boa administração ${ }^{26}$. De

22 Nos termos dessa competência, editadas as Resoluções 40/2001, 43/2001 e 48/2007, do Senado Federal.

23 Executivo e Legislativo andam lado a lado, sendo sempre necessária a autorização legal para a contratação da qual resulta dívida pública. Mas a harmonia entre os poderes, vale frisar, deve-se irradiar em toda a atividade financeira. Em obra que discute o poder financeiro no escopo da separação de poderes, cf. FERREIRA, 2018a.

${ }^{24}$ No particular, ressalta Licurgo Mourão: “A Lei Complementar n. 101/2000, estabeleceu normas de finanças públicas cujo objetivo era introduzir mecanismos que ensejassem a obrigatoriedade de práticas que levassem ao controle efetivo dos gastos públicos, com reflexos na menor dependência de recursos de terceiros, com o consequente soerguimento da capacidade de investimento do Estado" (MOURÃO, 2010, p. 241).

${ }^{25}$ José Mauricio Conti explica que a LRF adotou, ainda, regras para evitar que um ente da Federação financie a outro, o que causaria embaraços em uma federação assimétrica como a brasileira (CONTI, 2007, p. 243).

26 Juarez Freitas defende boa administração como direito fundamental: "Nesse desiderato, o direito fundamental à boa administração pública (conceito enunciado em debates brasileiros, sob a inspiração do art. 41 da Carta dos Direitos Fundamentais de Nice), é norma implícita de 
fato, hoje, não há como se cogitar a atividade financeira do Estado sem inseri-la dentro do contexto de responsabilização fiscal, sobretudo no que toca ao controle do endividamento público, garantindo-se uma sistemática de atuação estatal que evite déficits imoderados e se oponha à expansão indesejável da dívida, com vistas ao desenvolvimento sustentável. Dentre os limites para o endividamento no ordenamento pátrio, há de se destacar a norma capital que se convencionou chamar de "Regra de Ouro", insculpida na Constituição Federal de 1988 (art. 167, III) e reproduzida na Lei de Responsabilidade Fiscal (art. 12, $\mathbb{S} 2^{\circ}$ ), a respeito da qual agora se passa a desenvolver a presente análise.

\section{A REGRA DE OURO BRASILEIRA E SUA DISCIPLINA NORMATIVA}

Premissa central no regramento da dívida pública brasileira, a Regra de Ouro se trata de disposição constitucional que impõe uma vedação à realização de operações de crédito que excedam o montante das despesas de capital. O princípio básico dessa disciplina encontra apoio na visão orçamentária que distingue as despesas passíveis de serem financiadas pela via das operações de crédito (despesas de capital) daquelas outras em que fica obstada a fonte de financiamento pela via do endividamento (despesas correntes) ${ }^{27}$. A situação ideal sugere que as receitas correntes sejam mais do que suficientes para custear as despesas correntes, de modo que, gerado o excedente (superávit corrente), inevitavelmente as operações de crédito se fariam limitadas ao atendimento das despesas de capital, sempre em montante inferior a elas (déficit de capital). Quando esse equilíbrio fiscal é rompido, abre-se espaço à perigosa espiral, em que empréstimos são tomados para suportar despesas correntes, indício claro de descontrole das contas públicas. A legislação pátria busca rechaçar tal ocorrência por meio da Regra de Ouro, nos termos do que dispõe o art. 167, III da Lei Maior ${ }^{28}$ :

imediata eficácia em nosso sistema, a impelir o controle "lato sensu” a enfrentar a discricionariedade fora ou aquém dos limites" (FREITAS, 2014, p. 13).

27 As receitas e despesas orçamentárias classificam-se, quanto à categoria econômica, em correntes e de capital, a teor da Lei n. 4320/64 (normas gerais de direito financeiro), contendo nos artigos 11 e 12 suas subespécies.

28 Antonio Carlos d'Ávila lembra que antes da promulgação da Constituição de 1988, a Carta de 1967 previa, no seu art. $66, \mathbb{\$} 1^{\circ}$, que o equilíbrio formal entre receitas e despesas poderia ser dispensado, com vistas à "execução de política corretiva de recessão econômica”, bem como em favor de despesas "à conta de créditos extraordinários". Essa regra vigorou apenas por dois anos, pois a Emenda Constitucional n. 1/1969, retirou os dispositivos que consagravam o equilíbrio orçamentário. Ademais, tal Emenda autorizou a colocação e o resgate de títulos do Tesouro para amortização de empréstimos sem autorização legislativa orçamentária. Em todo o pe- 
Art. 167. São vedados: (...)

III - a realização de operações de créditos que excedam o montante das despesas de capital, ressalvadas as autorizadas mediante créditos suplementares ou especiais com finalidade precisa, aprovados pelo Poder Legislativo por maioria absoluta;

Em reforço ao texto constitucional, também a Lei de Responsabilidade Fiscal invoca a previsão da Regra de Ouro, conforme se extrai do seu art. $12, \mathbb{S} 2^{\circ}$ (“o montante previsto para as receitas de operações de crédito não poderá ser superior ao das despesas de capital constantes do projeto de lei orçamentária”). Outros dispositivos na LRF, ainda, robustecem a importância do cumprimento dessa regra de equilíbrio fiscal, seja como requisito para contrair novas operações de crédito por quaisquer dos entes da Federação (art. 32, $\mathbb{S} 1^{\circ}, \mathrm{V}$ e $\mathbb{S} 3^{\circ}$ ), seja na imposição de constituição de reserva específica para o exercício financeiro seguinte caso haja seu eventual descumprimento (art. $33, \mathbb{S} 4^{\circ}$ ), ou ainda, na exigência de demonstrativo quanto ao efetivo atendimento no Relatório Resumido da Execução Orçamentária do último bimestre do exercício correspondente (art. 53, $\left.\mathbb{S} 1^{\circ}, \mathrm{I}\right)$. Em todo caso, não há dúvidas de que se sobressai o papel fundamental da Regra de Ouro para o equilíbrio das contas públicas e a manutenção do endividamento em padrões toleráveis.

A razão que perpassa a disciplina normativa de limitação às operações de crédito é simples: sendo as despesas tidas por correntes e de capital (art. 12 da Lei n. 4.320/64), enquanto aquelas se referem aos recursos aplicados de forma permanente na manutenção das atividades estatais e se destinam ao funcionamento da máquina pública, as despesas de capital, ao revés, aplicam-se em demandas eventuais, que possuem, em essência, o potencial de alavancagem do patrimônio estatal. Em outros termos, as primeiras, oneradas pela periodicidade e destinadas à cobertura do presente, asseguram o provimento atual da estrutura administrativa (custeio); as segundas, por sua vez, gravadas pela eventualidade e direcionadas para o futuro, propiciam o acréscimo patrimonial e guardam a natural aptidão para o ganho posterior do capital aplicado (investimentos). O que a Regra de Ouro busca produzir, na verdade, é uma barreira para evitar que recursos oriundos de operações de crédito, marcados pela obrigação estatal futura de restituição do valor recebido acrescido dos juros, sejam aplicados em despesas cotidianas

ríodo que antecede a Constituição de 1988, portanto, não havia disposição que limitasse a relação entre operações de crédito e despesas de capital. É apenas com o advento da Lei Maior de 1988 que o ordenamento jurídico nacional passa a limitar, por meio da regra de ouro, as operações de crédito, buscando o endividamento mais justo e sustentável em termos intertemporais (CARVALHO JUNIOR et al., 2017, p. 4). 
não potencialmente viabilizadoras de incremento patrimonial. É que se faz necessário o retorno a ser gerado adiante para viabilizar os custos do endividamento do presente. Só assim o valor projetado superará seu financiamento, e então, harmoniza-se à noção de sustentabilidade da dívida no tempo ${ }^{29}$. Pretendem-se, com efeito, o desenvolvimento sustentável e o controle da dívida pelo bloqueio de sua exacerbação para além das despesas de capital ${ }^{30}$.

Outrossim, tal limitação reveste-se de importância singular para a compatibilização do endividamento com os critérios de justiça intergeracional, na medida em que, por meio da dívida, uma parcela dos financiamentos é transferida para a geração vindoura. Nesse ponto, tem-se uma dupla face da mesma moeda: de um lado, incorpora-se no conceito intertemporal de justiça o compartilhamento dos encargos de financiamentos com as gerações futuras que serão beneficiárias dos investimentos feitos no presente por meio das operações de crédito ${ }^{31}$; de outro lado, para que seja assegurado esse princípio de justiça intergeracional ${ }^{32}$, obviamente, só faz sentido transmitir à geração vindoura os encargos decorrentes de

29 Diz-se que a sustentabilidade da dívida é definida em função de quatro fundamentais variáveis: (1) Tamanho; (2) Composição; (3) Descasamento; (4) Credibilidade (MENDONÇA et al., 2005, p. 17). Intrínseco à noção de sustentabilidade da dívida está o desafio de sua solvência pelo Estado. A propósito: "A dívida pública deixa de ser sustentável quando o governo é avaliado como incapaz de pagá-la nos termos contratados. Em situações como essa, esses termos precisam ser revistos para que a dívida se ajuste às condições financeiras do governo, renegociação que pode ou não ocorrer de modo ordenado" (PELLEGRINI, 2017, p. 30-31).

30 Em estudo da Instituição Fiscal Independente (IFI) há a explicitação dos pontos a favor da vedação, mas a validade dos argumentos depende do tipo de investimento qualificado pela Regra de Ouro. A definição ideal exigiria que investimentos restritos aos projetos com potencial de gerar retornos suficientemente elevados em receitas, produtividade e crescimento econômico. $\mathrm{Na}$ direção oposta, quando sua operacionalização diverge muito da configuração clássica, há maior suscetibilidade de problemas que podem tornar a regra fiscal incompatível com seus objetivos originários (COURI; SALTO; BARROS; ORAIR, 2018, p. 7-9).

31 Tendo em vista o uso de renda futura para honrar operações de crédito, diz-se que "empréstimos são tributos antecipados, ou seja, comprometem os tributos que serão arrecadados pelas futuras gerações para pagamento dos gastos realizados pela atual geração" (SCAFF, 2016, p. 127). De outro modo, também explica José Joaquim Teixeira Ribeiro: “os empréstimos contraídos pelo Estado são um processo de transferir da geração presente para as gerações vindouras o ônus das despesas com ele financiadas” (RIBEIRO, 1997, p. 228).

32 Sobre intergeracionalidade, explica John Rawls: "as pessoas de diferentes gerações têm deveres e obrigações em relação uma às outras exatamente como as têm as pessoas que vivem numa mesma época. A geração atual não pode fazer o que bem entender, mas é obrigada, por princípios que seriam escolhidos na posição original, a definir a justiça entre as pessoas que vivem em épocas diferentes" (RAWLS, 1997, p. 324-325). 
operações de crédito que se destinem exclusivamente à cobertura de investimentos, do contrário, se utilizadas para o custeio de despesas correntes, os futuros contribuintes estarão sendo levados a pagar por gastos públicos cujos benefícios foram totalmente usufruídos pela geração atual. É por isso que a Regra de Ouro tem por efeito, ainda, estabilizar a equidade intergeracional, porquanto as despesas correntes não têm, em essência, o potencial de incremento patrimonial esta$\mathrm{tal}^{33}$. A inobservância dessa regra resulta em empréstimos destinados para despesas restritas ao presente, quebrando-se a lógica da justiça intertemporal que a dívida pública poderia gerar.

É possível, então, por diversos motivos, identificar elementos favoráveis à Regra de Ouro. A rigor, a norma constitucional impeditiva das operações de crédito que excedam as despesas de capital estabelece o vínculo que liga dois universos nos quais está imerso o endividamento público: (i) o fortalecimento do patrimônio público e o favorecimento do crescimento econômico como efeitos; (ii) a manutenção da sustentabilidade fiscal e a garantia da justiça intergeracional como premissas. Na conexão entre ambos, de modo a se alcançar o primeiro sem desbordar do segundo, está o respeito aos limites da dívida, para os quais se dirige a Regra de Ouro. A verdade é que o controle do endividamento público se torna condição para manter os próprios princípios que o legitimam. A dívida pública, para subsistir, precisa conviver com limites, fora dos quais seu benefício potencial se reverte em nocividade. Foi o que buscou o constituinte ao inserir a Regra de Ouro como princípio constitucional vinculado ao ideal de responsabilidade fiscal. Em que pese a sua previsão, todavia, um exame mais atento pode revelar que tal regra não é tão rígida como parece, daí por que essa vedação, na prática, não tem sido historicamente suficiente para conter desvios em suas premissas.

Em primeiro plano, da literalidade do texto insculpido no art. 167, III, CF/88, se bem analisado, não se extrai propriamente a previsão expressa no sentido de efetiva proibição da destinação de recursos oriundos das operações de crédito para o custeio de despesas correntes. Essa é uma interpretação que se faz, a contrario sensu, daquilo que foi previsto na cláusula constitucional ${ }^{34}$. $\mathrm{Na}$ verdade, a

${ }^{33}$ É importante ressalvar que mesmo a existência da Regra de Ouro não garante, por si só, que tal premissa seja realizada, dependendo ainda da qualidade dos investimentos: “(...) o investimento público possui um elevado efeito multiplicador. Dessa forma, é um item da despesa com maior impacto sobre o crescimento econômico de forma que a sua expansão não criaria riscos diretos ou permanentes para a sustentabilidade fiscal. Isso é tão mais verdade quanto melhor for a carteira de projetos de investimento em execução" (PIRES, 2018, p. 4).

34 A propósito, explica Weder de Oliveira que a Constituição não vincula a realização de operações de crédito à sua aplicação em despesas de capital, nem proíbe o uso de receitas de operações de 
disciplina de vedação à realização de operações de créditos que excedam o montante das despesas de capital não necessariamente exclui a possibilidade de que, respeitado tal limite, possam ser aplicadas tais operações na cobertura de despesas correntes. A proibição trazida pelo art. 167, III, da CF/88, em seu sentido literal, não obstrui a contratação de operações de crédito para o custeio de despesas correntes, mas o que se veda é somente que tais operações excedam o montante das despesas de capital. É óbvio que tal interpretação, naturalmente, não é a que melhor favorece o respeito às premissas da justiça intergeracional e da sustentabilidade da dívida. Mas o fato é que a Regra de Ouro brasileira, na verdade, dirige-se mais ao estabelecimento de um limite quantitativo do que à idealização de uma norma que propicie o controle qualitativo do endividamento.

Por outro lado, o enunciado do art. 167, III, da Constituição Federal de 1988, é uma versão mais flexível da Regra de Ouro clássica, a qual só admite operações de crédito para a realização de investimentos e não adota o conceito ampliado de despesas de capital para fins de limite máximo de tais operações. A propósito, nos termos do art. 12 da Lei 4.320/64, são três as modalidades de despesas de capital: (a) investimentos; (b) inversões financeiras; (c) transferências de capital. Na medida em que o texto da Constituição brasileira considera todas as despesas de capital teto para as operações de crédito, sem qualquer distinção entre suas espécies, abre-se margem para que esse instrumento não se restrinja exclusivamente aos investimentos, porquanto também as inversões financeiras e a amortização da dívida integram as despesas de capital. Não há dúvidas, pois, de que a Regra de Ouro brasileira possui maior benevolência, se confrontada com a versão clássica da norma, em relação aos limites nos quais estão circunscritas as operações de crédito. Se é recomendável, porém, que os recursos decorrentes do endividamento resultem em potencial ganho futuro, seja para possibilitar a sua sustentabilidade no tempo, seja para garantir equidade intergeracional, surge daí o debate se a cláusula de vedação, para fins de limitação da dívida, haveria de ser mais restritiva como em sua versão tradicional, de modo a guardar relação estreita com as despesas de capital que se destinam ao incremento patrimonial (investimentos públicos). $\mathrm{Na}$ ordem pátria, inexistindo tal previsão, nada impede que sejam incluídas inversões financeiras e amortizações no cômputo da Regra de Ouro. Eis um dos motivos, aliás, para que o cumprimento formal da

crédito para financiar despesas correntes, ao contrário do que sugere uma primeira leitura do dispositivo, que se faz equivocada: "A regra constitucional brasileira é sutilmente diferente na redação, mas substancialmente diferente em suas implicações: estabelece, em leitura reversa, que o montante das operações de créditos não pode ser superior ao montante das despesas de capital. Isso quer dizer que a Constituição não veda expressamente a destinação de recursos oriundos de operações de crédito para custear despesas correntes" (OLIVEIRA, 2015, p. 825). 
norma constitucional conviva historicamente com a existência de déficits crescentes no Brasil ${ }^{35}$.

Ademais, há que se ponderar também sobre os investimentos das empresas estatais não dependentes para fins de apuração da Regra de Ouro, o que pode elevar o volume das operações de crédito e gerar importantes distorções. Relembre-se que a Constituição de 1988 , no art. 165 , $\mathbb{S} 5^{\circ}$, ao criar o modelo de planejamento orçamentário brasileiro, estipulou que o orçamento anual compreende: (i) Orçamento Fiscal (OF), referente aos Poderes da União, seus fundos, órgãos e entidades da administração direta e indireta, inclusive fundações instituídas e mantidas pelo Poder Público; (ii) Orçamento da Seguridade Social (OSS), abrangendo entidades e órgãos a ela vinculados, da administração direta ou indireta, bem como os fundos e fundações instituídos e mantidos pelo Poder Público; e (iii) Orçamento de Investimento (OI), específico para as empresas em que a União, direta ou indiretamente, detenha a maioria do capital social com direito a voto. Quanto a esse último, diferentemente das entidades financiadas por recursos públicos (incluídas no OF e OSS), as empresas estatais não dependentes são custeadas por recursos próprios e atuam sob regime jurídico de direito privado, possuindo natureza diversa daquelas. O maior alcance da Regra de Ouro, incluindo também as empresas estatais não dependentes, pode ser manejado como subterfúgio para o aumento, por vezes ilusório, da capacidade de endividamento do Estado ${ }^{36}$.

E, ainda, resta observar que a cláusula constitucional da Regra de Ouro brasileira não é limite intransponível, a se verificar pela ressalva expressa ao final do art. 167, III, CF/88, sendo possível a excepcional realização de operações de créditos que excedam o montante das despesas de capital, hipótese que se valida mediante três requisitos: (1) existência de lei que autorize o crédito adicional; (2)

35 Análises da Instituição Fiscal Independente (IFI) apontam que a Regra de Ouro foi formalmente cumprida sob condições de investimentos estáveis, elevados déficits correntes e endividamento crescente. Em resposta ao questionamento sobre o que explica tal enigma, conclui-se: “(...) algumas peculiaridades do desenho e da operacionalização da Regra de Ouro brasileira que fazem com que ela se afaste da configuração clássica apresentada na seção anterior. A primeira das peculiaridades é que o governo federal dispõe de um volume elevado de receitas financeiras (...). A segunda peculiaridade é que a Regra de Ouro brasileira está baseada em um conceito amplo de despesas de capital” (COURI; SALTO; BARROS; ORAIR, 2018, p. 12-13).

36 As empresas estatais não dependentes seguem regime de direito privado, até sua contabilidade não apresenta a dicotomia típica da esfera pública entre despesas correntes e de capital, podendo ter situações inusitadas ao onerar o limite de operações de crédito com operações daquelas (NASCIMENTO; DEBUS, 2002, p. 56). E ainda, cabe notar: "A situação é mais sensível quando damos conta de que, independentemente do percentual de participação do ente controlador na empresa estatal, todas $(100 \%)$ as despesas de investimento são levadas ao OI e, por consequência, ao cômputo da 'regra de ouro'.” (CARVALHO JUNIOR et al., 2018, p. 25). 
destinação do recurso com finalidade precisa; (3) aprovação parlamentar por maioria absoluta. A previsão terá aplicabilidade, óbvio, durante a execução do orçamento, não se cogitando sua ocorrência no curso do projeto orçamentário, por se tratar de perda atípica da estabilidade original, tolerável apenas ao longo do exercício ${ }^{37}$. Note-se, porém, que tal ressalva não foi inserida na Lei de Responsabilidade Fiscal, limitando-se esta a prever, no art. $12, \mathbb{S} 2^{\circ}$, a vedação de operações de crédito em montante superior às despesas de capital constantes do projeto de lei orçamentária. Sobre o tema, pronunciou-se o STF na ADI n. 2.238-5, para conferir ao dispositivo interpretação conforme ao art. 167, III, da CF/88. De todo modo, apesar do entendimento da Suprema Corte, não parece ter havido deliberado vício de inconstitucionalidade na LRF, uma vez que o dispositivo atacado se direcionou ao projeto de lei orçamentária, etapa que, como dito, é insuscetível de excepcionalidade ${ }^{38}$.

Da necessidade de sua observância ainda na fase de elaboração do projeto se extrai a evidência de que a Regra de Ouro foi projetada para ser aplicada ao longo de todo o ciclo orçamentário, seja durante a execução do orçamento, fase em que se faz cabível sua mitigação quando preenchidos os requisitos presentes na ressalva expressa do art. 167, III, CF/88, seja no momento da elaboração do orçamento, etapa em que, por razões óbvias, nada justificaria ser impulsionado o projeto, já na sua concepção, com desequilíbrio entre operações de crédito e despesas de capital. Contrariando a lógica, porém, o PLDO 2019, convertido na Lei n. 13.707 , de 14 de agosto de 2018, inovou ao trazer pela primeira vez a esdrúxula autorização para que o excedente de operações de crédito em relação às despesas de capital seja previsto já no Projeto da Lei Orçamentária de 2019, por meio das chamadas operações de crédito condicionadas ${ }^{39}$. A proposição é um claro

37 A propósito: “Seria razoável, ou faria sentido admitir que a programação do projeto de lei orçamentária não respeitasse a regra de ouro? Não apenas não faria sentido como a leitura correta da Constituição assim exige, uma vez que a exceção à regra somente é admitida por meio de autorização dada em créditos adicionais, ou seja, em projetos de lei que modificam a lei orçamentária na versão original” (OLIVEIRA, 2015, p. 827).

38 Trata-se, pois, de exceção: “A regra geral continua sendo a impossibilidade de a lei orçamentária contemplar previsão de operações de crédito superior às despesas de capital, e a única exceção permanece que durante a execução orçamentária o Legislativo poderá por maioria absoluta aprovar créditos adicionais - suplementares ou especiais -, permitindo a extrapolação deste limite" (FIGUEIREDO; NÓBREGA, 2006, p. 100).

39 Nesse sentido, o inusitado art. 21 da Lei n ${ }^{\circ} 13.707 / 2018$, que dispõe sobre as diretrizes para a elaboração e execução da Lei Orçamentária de 2019: “O Projeto de Lei Orçamentária de 2019 e a respectiva Lei poderão conter, em órgão orçamentário específico, receitas de operações de crédito e programações de despesas correntes primárias, condicionadas à aprovação de projeto 
prenúncio de fragilização da Regra de Ouro, ao se permitir sua flexibilização na elaboração do projeto orçamentário, embora o evento propulsor da invocação da excepcionalidade somente surja no momento da execução do orçamento. A rigor, a alteração no PLDO 2019 exterioriza um fenômeno maior, sinalizando a dificuldade atual para o cumprimento da Regra de Ouro no Brasil, como agora se passa a analisar.

\section{O DEBATE SOBRE A RELATIVIZAÇÃO DA REGRA DE OURO NO BRASIL}

Em que pese a versão menos rígida da Regra de Ouro no contexto da dívida pública brasileira, atualmente se eleva o indicativo da dificuldade no seu atendimento, renovando-se o debate acerca da necessidade de alteração da norma constitucional para fins de equacionar as contas públicas e tornar factível o seu efetivo implemento ${ }^{40}$. De fato, nos últimos anos, apesar de a vedação contida no art. 167 , III da CF/88 ter sido respeitada no plano formal, passou-se a observar um progressivo estreitamento entre o montante das despesas de capital e o volume de receitas oriundas de operações de crédito, projetando-se uma iminente incapacidade de atendimento da Regra de Ouro para exercícios vindouros, associada, ainda, à grave situação atual da dívida pública brasileira, que voltou a atingir elevados patamares em relação aos seus padrões históricos, transparecendo perspectivas nada animadoras.

A propósito, em análise no âmbito do Núcleo de Estudos e Pesquisas da Consultoria Legislativa do Senado Federal ${ }^{41}$, revela-se que, no período de 2014 a 2016, a dívida bruta do governo geral (DBGG) subiu de forma vigorosa, passando de 51,5 para $69,5 \%$ do PIB em dezembro de 2016 , com a projeção de percentual ainda maior para os próximos anos, mesmo com o Novo Regime Fiscal inserido pela EC n. 95/2016, estimando-se um patamar acima de 85\% do PIB em 2020. Por sua vez, estudo técnico no âmbito da Consultoria de Orçamentos e Fiscalização Financeira da Câmara dos Deputados ${ }^{42}$, tendo por base números anunciados

de lei de créditos suplementares ou especiais por maioria absoluta do Congresso Nacional, de acordo com o inciso III do art. 167 da Constituição.

40 Notícia divulgada nos diversos meios de comunicação no início de 2018 acerca da possível propositura de PEC pelo governo federal para flexibilizar a Regra de Ouro. A título ilustrativo, http://g1.globo.com/jornal-hoje/noticia/2018/01/governo-planeja-mudar-regra-de-ouro-para-evitar-crime-de-responsabilidade.html. O debate foi arrefecido com a intervenção federal ocorrida no país, condição impeditiva à alteração da CF/88.

41 Dados revelados no "Textos para Discussão no 226" (CONLEG/Senado). Cf. PELLEGRINI, 2017, p. 36.

42 Números colhidos do "Estudo Técnico n. 9/2018" (CONOF/Câmara). CF. ALMEIDA; BIJOS, 2018, p. 2-3. 
pela Instituição Fiscal Independente (IFI), corrobora o exposto ao apontar que a dívida bruta, já situada em $75,9 \%$ do PIB em abril de 2018 , pode atingir proporções gravosas com o indicativo de 86,6\% do PIB em 2023, sugerindo a necessidade de um superávit primário da ordem de 1,13\% do PIB para a estabilização da dívida bruta federal no patamar de $69,9 \%$ do PIB, nível observado ao final de 2017, resultado esse, porém, que o governo provavelmente só passará a gerar, em cenário otimista, em 2023, sendo o cenário-base mais provável em 2026.

Essa realidade que perpassa o contexto atual da dívida pública brasileira também se conecta à discussão sobre a redução da margem de cumprimento da Regra de Ouro. Segundo informativo da Coordenação-Geral de Planejamento Estratégico da Dívida Pública (COGEP) no âmbito da Secretaria do Tesouro Nacional ${ }^{43}$, a partir de 2012, identificou-se um acentuado declínio na folga para o seu atendimento, caindo de $\mathrm{R} \$ 286,0$ bilhões até chegar, em 2017, ao patamar diminuto de $\mathrm{R} \$ 28,8$ bilhões. A tendência se intensificou em 2018 com a expectativa real da violação à Regra de Ouro, prevendo-se uma insuficiência de R \$ 181,9 bilhões para sua observância, contornável apenas pelo socorro vindo da devolução antecipada de empréstimos pelo BNDES no valor de R \$ 130 bilhões, além do cancelamento de restos a pagar na monta de $\mathrm{R} \$ 20$ bilhões, assim também pela extinção do Fundo Soberano e do Fundo Nacional de Desenvolvimento, com alcance de R $\$ 43$ bilhões, bem como outras medidas de otimização de recursos e alocação do superávit financeiro de 2017, totalizando mais R \$ 18,9 bilhões.

Não obstante as engenhosas providências para o cumprimento da Regra de Ouro, os anos que seguem revelam um cenário ainda mais desafiador. Para os três próximos exercícios, consoante informe da Secretaria do Tesouro Nacional, conjecturam-se desfalques projetados da ordem de R \$ 260,2 bilhões, R \$ 307,3 bilhões e R \$228,4 bilhões, respectivamente, entre 2019 e 2021, sem qualquer sinalização de mudança de sentido em direção à trajetória positiva para a margem de cumprimento da Regra de Ouro ${ }^{44}$. Estimativas para períodos mais dilatados

${ }^{43}$ Informe Dívida (mai/18). Projeções para Regra de Ouro. Disponível em: http://www.tesouro. fazenda.gov.br/ documents/10180/ 659854 /Regra+de+Ouro+Informe+30-05/41c50e2b-ccf4486a-905e-564973ad5394.

${ }^{44}$ Em complemento, importante ressalva extraída do Informe Dívida de Maio/18 - Projeções para a Regra de Ouro: "Além disso, não é apenas o déficit primário que pressiona a emissão de dívida para a cobertura de despesas correntes. Os juros da dívida também concorrem com os demais gastos correntes, e na ausência de receitas primárias suficientes, acabam pressionando a utilização de receitas de operação de crédito. Devido ao forte crescimento da dívida pública nos últimos anos, e do perfil de vencimentos, essa conta de juros também vem aumentando, e atingirá valores ainda mais elevados nos próximos anos. (...) Diante disso, podemos concluir que não é suficiente que o resultado primário fique positivo para que se equacione a utilização de receitas de operação 
podem ser vistas, ainda, em criteriosa análise realizada no âmbito do Senado Federal pela Instituição Fiscal Independente (IFI) ${ }^{45}$, incluindo projeções até o exercício de 2025, que reforçam a grave situação para o atendimento atual e futuro da Regra de Ouro. Nos termos do aprofundado estudo, diagnostica-se que a insuficiência da margem de atendimento da cláusula constitucional deve perdurar por largo período, prevendo-se o seu descumprimento dentro de um lapso temporal que tende a se arrastar entre os exercícios de 2019 e 2024, retomando uma possível inclinação positiva somente sete anos após o corrente exercício.

No interregno negativo da margem de descumprimento da Regra de Ouro projetada pela referida Instituição, obteve-se um resultado sequencial desfavorável que evidencia a elevação estimada do montante das operações de crédito em relação às despesas de capital na ordem de $\mathrm{R} \$ 98,8$ bilhões (2019), R \$ 90,5 bilhões (2020), R \$ 115,0 bilhões (2021), R \$ 67,8 bilhões (2022), R \$ 35,0 bilhões (2023) e, R \$ 0,7 bilhões (2024), voltando-se apenas em 2025 à curva ascendente. Embora se perceba a inexistência de correspondência exata entre os valores previstos pela STN e pela IFI para a margem de atendimento da Regra de Ouro - fato que se mostra plenamente compreensível pela alta complexidade das variáveis de cálculo envolvidas - o que importa é que para ambos converge a indicação de um sensível período de violação à norma, sendo uníssonos quanto a sua factual iminência:

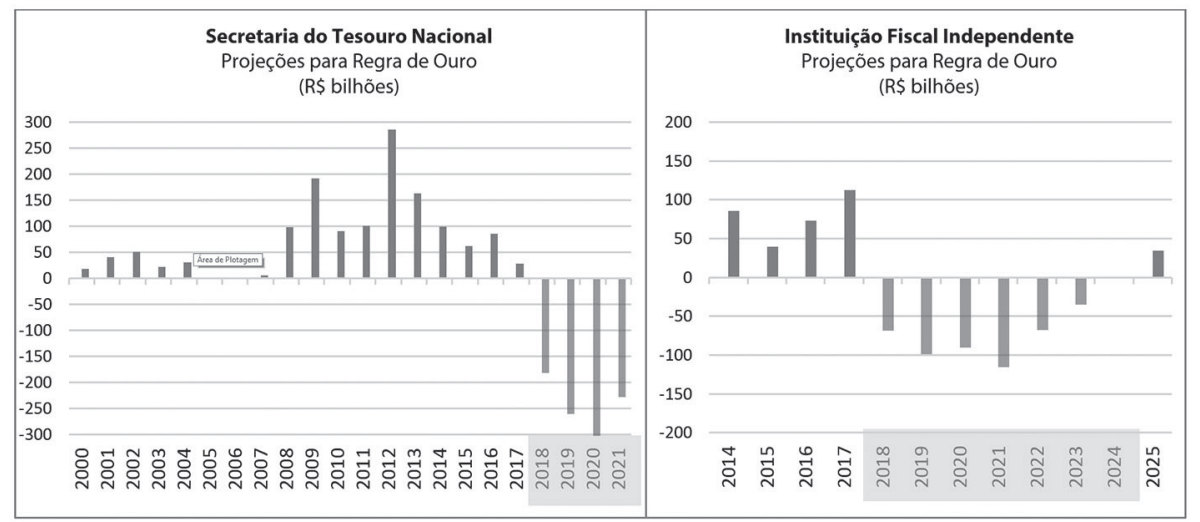

\section{Gráfico 1 - Estimativas de insuficiência de recursos para cumprimento da Regra de Ouro (STN e IFI).}

Fonte: Elaborado pela autoria.

de crédito no montante das despesas de capital. É necessário que esse superávit primário seja suficiente para pagar uma parte significativa dos juros da dívida" (BRASIL, 2018, p. 5).

${ }_{45}$ Dados colhidos no Estudo Especial n. 5/2018 (IFI). Cf. COURI; SALTO; BARROS; ORAIR, 2018, p. 40-43. 
A deficiência quantitativa de recursos para atender à Regra de Ouro já incita, por si só, discussões palpitantes, mas a realidade se torna ainda mais complexa quando se vislumbra, nos últimos anos, a perda da qualidade dos recursos usados para integrar essa margem, a despeito de o eixo do debate se situar, quase sempre, apenas no exame da adequação formal à cláusula constitucional. Mais importante do que o volume dos recursos para o cumprimento da Regra de Ouro, contudo, é a percepção qualitativa das receitas que vem sendo utilizada para tal desiderato, na medida em que se constata uma gradativa deterioração nesse aspecto. Aliás, a análise realizada no âmbito do Senado Federal pela Instituição Fiscal Independente revela que o cumprimento intertemporal da Regra de Ouro vem sendo recorrentemente alcançado graças ao elevado nível de receitas financeiras obtidas por fontes diversas, como no caso do repasse do resultado positivo do Banco Central, entre tantas outras acrescidas de modo significativo, sem as quais restaria verdadeiramente descumprida a Regra de Ouro ${ }^{46}$.

Some-se a isso, como dito alhures, a consideração extensiva do conceito de despesas de capital para fins de consideração da Regra de Ouro, não havendo sua limitação apenas aos investimentos, bem como a inexistência de real bloqueio à utilização das operações de crédito para o custeio de despesas correntes, conforme se depreende da interpretação literal do art. 167, III da CF/88. Tudo resulta em uma norma que, na prática, não propicia maior qualidade à dívida, por se voltar à exclusiva fixação de critério quantitativo. Se a Regra de Ouro, em sua versão clássica, associa-se a importantes premissas, como o equilíbrio do orçamento corrente, a elevação patrimonial pela via dos investimentos, a sustentabilidade da dívida no tempo e a equidade entre as gerações, não há dúvidas de que, inevitavelmente, tais parâmetros acabam sendo frustrados no desenho da regra no ordenamento pátrio. Não por outra razão, apesar de formalmente cumprida nos anos anteriores, a Regra de Ouro não constituiu obstáculo para a ocorrência de elevados déficits correntes e um endividamento crescente ${ }^{47}$.

${ }^{46}$ O cenário crítico é ressaltado: "Ao expurgar o repasse do resultado do Banco Central, uma receita financeira, teria ocorrido descumprimento da Regra de Ouro em quatro períodos: 2005, 2015, 2016 e 2017. Para uma métrica mais restrita, que exclui não apenas o resultado do Banco Central mas todas as demais receitas financeiras, haveria descumprimento em onze dos treze anos analisados: apenas em 2008 e 2012 a regra fiscal teria sido cumprida. Do ponto de vista do conceito mais rigoroso e normativo, que desconsidera tanto as receitas financeiras supracitadas quanto as despesas de capital não primárias (ou financeiras), a regra teria sido descumprida em todos os anos da série" (COURI; SALTO; BARROS; ORAIR, 2018, p. 25-27).

47 Sobre esse ponto também se posiciona a análise realizada pela Instituição Fiscal Independente ao afirmar que a despeito do cumprimento da regra de ouro existe um sistemático déficit corrente, tendo-se um enigma não resolvido na medida em que esta é uma norma de déficit corrente 
De fato, seja pela disponibilidade de várias receitas financeiras alheias à gestão, seja pelo conceito dilatado de despesas de capital na realidade brasileira englobando não apenas investimentos, seja pela falta de suporte para o efetivo controle das contas ante a ausência de vedação às operações de crédito para custeio de despesas correntes, tem-se um arranjo bem peculiar da Regra de Ouro no contexto da dívida pública brasileira e bastante descolado dos princípios clássicos que a permeiam, vindo à tona a inevitável fragilização do modelo não só no que tange à redução da margem para o seu cumprimento perante as projeções negativas para os exercícios vindouros, mas, sobretudo, quanto à perspectiva de depreciação qualitativa do seu cumprimento. Torna-se insustentável o atendimento da Regra de Ouro no plano formal se ela não estiver também conectada com a preservação de critérios assecuratórios da sua permanência no tempo ${ }^{48}$. No ponto, reforça-se o exposto em linhas preliminares para recordar que a dívida é peça fundamental ao Estado desde que respeitadas as premissas que conservam a sua vocação original, fora das quais se deslegitima a sua aplicação no tecido social ${ }^{49}$.

nulo ou resultado corrente equilibrado. Esse resultado ficou fortemente negativo a partir de 2014 pelo aumento de gastos com juros e geração continuada de déficits primários. Nos termos do estudo, afirma-se que em 1998 o déficit corrente era de 4,1\% do PIB, tendo ficado mais contido no período de 2007 a 2012, para em seguida avançar ao nível de 8,3\% do PIB em 2015, chegando atualmente ao nível de cerca de $6,9 \%$ do PIB. A rigor, o Brasil vem formalmente cumprindo a regra de ouro por meio de receitas financeiras, sobretudo, do Banco Central e do BNDES, mas a magnitude do indicador da dívida em relação ao PIB revelaria que o orçamento corrente é bastante deficitário e caminha na direção oposta à literatura clássica da regra de ouro (COURI; SALTO; BARROS; ORAIR, 2018, p. 36).

48 "O endividamento/déficit pode ser classificado como bom ou ruim, a depender do tipo de gasto que está sendo efetuado (investimento imobilizado, investimento em capital humano, abertura de mais vagas no serviço público ou singelo consumo de bens e serviços, dentre outros) e da situação econômica do Estado em face de vários outros fatores, tais como o nível de endividamento precedente ou o volume de despesas obrigatórias. (...) O ponto central do problema está no tipo de utilização que se deve dar a esses recursos. Se estes se destinarem ao ralo das despesas correntes, o endividamento será pernicioso e demonstrará, em médio/longo prazo, um desequilíbrio, uma insustentabilidade financeira (SCAFF; ATHIAS, 2016, p. 90-91).

49 A propósito, ao prefaciar valiosa obra sobre dívida pública, expõe Murilo Portugal: "Quando utilizada para financiar o investimento público produtivo, a dívida pública pode funcionar tanto como um mecanismo de equidade intergeracional quanto como um sistema de baixo risco de transferência intertemporal de consumo, gerando resultados sociais positivos (...) O pagamento de despesas públicas correntes de consumo deve ser normalmente realizado com impostos e não com dívida pública. Financiar uma proporção grande e crescente do consumo público com dívidas sujeitas ao pagamento de juros significa destruir a riqueza pública. A lógica da taxa de juros composta leva à conclusão inexorável de que tal procedimento é insustentável no 
Apesar de toda essa complexa contextura que adentra o debate sobre a Regra de Ouro no direito pátrio, tem-se visto sobressair, em especial no ambiente político, o argumento favorável à atenuação da norma, destituído, porém, de qualquer análise qualitativa, pautando-se somente no alarde da perspectiva de descumprimento da cláusula constitucional. Ataca-se, pois, a consequência, sem se debruçar sobre o que a causa. A verdade é que ganha destaque o discurso sobre a relativização da Regra de Ouro, mesmo com desprezo às premissas de fundo, tendo o debate se revigorado no Brasil, sobretudo no início de 2018, diante da real iminência de violação à norma. A rigor, não se nega a possibilidade de revisão dos limites impostos pela Regra de Ouro, notadamente em períodos cuja sua mantença se mostre economicamente enrijecida, mas o que se precisa refutar é a saída cômoda de se pensar como medida única a relativização de uma regra que já é sensivelmente modificada de sua configuração clássica ao invés de rever as bases que conferem a melhoria de sua qualidade.

Sendo a Regra de Ouro, na experiência brasileira, uma vertente mais elástica do que a sua previsão na configuração tradicional, de onde resulta certo afastamento em relação aos princípios centrais dela, é claro que discussões no sentido de torná-la ainda mais flexível não podem estar dissociadas do exame prévio sobre o que tem gerado seu real enfraquecimento. Indubitavelmente, a margem negativa para atendimento à regra não estaria tão próxima se não fosse a anterior falta de aderência às premissas que a subsidiam. $\mathrm{O}$ argumento que se volta ao simplório abrandamento de norma por demais fragilizada, sem a avaliação complementar que lhe confira sustentabilidade, não é, nem de longe, o bom caminho a trilhar. Mas essa realidade já se mostra visível, a se verificar pela tentativa de superação do art. 167, III, CF/88 sem o necessário processo de alteração formal, por meio do PLDO 2019, que, como já se advertiu, reinterpretou a norma para tornar admissível que o projeto da lei orçamentária preveja receitas de operações de crédito acima das despesas de capital, desde que condicionadas a créditos adicionais aprovados no exercício seguinte, na forma da ressalva da norma constitucional.

As chamadas "operações de crédito condicionadas" invertem o comando normativo que pressupõe a observância do equilíbrio entre operações de crédito e despesas de capital ao longo de todo o ciclo orçamentário. Ao se perfurar tal basilar premissa no PLDO 2019, tem-se verdadeiro estímulo para que despesas

\footnotetext{
longo prazo (...). Os problemas dos juros altos e dos calotes explícitos são principalmente o resultado de se abandonar os princípios clássicos de utilizar a dívida pública apenas para o financiamento do investimento público ou para despesas emergenciais e extraordinárias, em vez de usar endividamento para simplesmente satisfazer a proclividade de gastar sem tributar" (SILVA; CARVALHO; MEDEIROS, 2009, p. 14).
} 
correntes possam ser custeadas por meio de operações de crédito além do limite estabelecido na Constituição. É verdade que tais operações ficam condicionadas à aprovação pelo Parlamento, mas isso não exclui o vício inerente ao modelo. A propósito, relevante análise foi produzida pela Consultoria de Orçamento e Fiscalização Financeira (CONOF/Câmara dos Deputados) em conjunto com a Consultoria de Orçamentos, Fiscalização e Controle (CONORF/Senado Federal), rechaçando as operações de crédito condicionadas previstas no PLDO 2019, seja em virtude da flagrante inconstitucionalidade por afronta ao art. 167, III, CF/88, bem como pela contrariedade à legislação de estimativa de receita constante do art. $7^{\circ}, \mathbb{S} 2^{\circ}$ da Lei n. 4.320/64, como também pelo claro desincentivo à premissa da responsabilidade fiscal, entre vários outros fatores ${ }^{50}$.

Proposta dessa natureza apenas evidencia o descaso que ultimamente se observa em tema de finanças públicas ${ }^{51}$. A questão que se trava, contudo, é a necessidade de uma aferição equilibrada: de um lado, a admissibilidade de ajustes no sentido do aprimoramento da Regra de Ouro, inclusive quanto aos limites nela encartados, uma vez que não se trata de regra absoluta, tampouco imutável; por outro lado, tal análise não poderá se desviar da precisa noção de responsabilidade fiscal e endividamento sustentável que obrigatoriamente onera a atuação estatal, avanços incorporados após fracassos decorrentes do descontrole na gestão das contas públicas, para os quais não se pode retroceder. A baixa margem de cumprimento da Regra de Ouro não se cinge à superficial alteração de seus marcos.

50 Ver Nota Técnica Conjunta n. 1/2018 (“Subsídios à apreciação do projeto de Lei de Diretrizes Orçamentárias para 2019”), da qual se extrai a reflexão em combate às operações de crédito condicionadas, por fatores que detalhadamente especifica (Cf. BRASIL, 2018, p. 33-36). O entendimento é compartilhado, ainda, por Antonio Carlos Costa d'Ávila: “O papel de orientar a elaboração dos orçamentos atribuído pela Constituição às Leis de Diretrizes Orçamentárias (LDO) não se confunde com o de dispor sobre a elaboração e a organização da Lei Orçamentária Anual, matéria esta cujo tratamento a Constituição da República de 1988, por intermédio do art. $165, \mathbb{S} 9^{\circ}$, reservou à lei complementar. O mecanismo das "receitas e despesas condicionadas” não pode ser aplicado às receitas orçamentárias decorrentes de operações de crédito, mormente aquelas cuja realização darão azo à inobservância da 'regra de ouro'." (CARVALHO JUNIOR, 2018, p. 14).

${ }^{51} \mathrm{Na}$ valiosa obra "Levando o Direito Financeiro a sério", José Mauricio Conti, fazendo um balanço de práticas orçamentárias recentes, incluindo pedaladas fiscais e manobras de contabilidade criativa, posiciona-se: "Um escárnio. Difícil saber, a essa altura, o que poderá ser feito para surpreender, pois a impressão é que todos os limites da improvisação e desconsideração total pelo ordenamento jurídico em matéria financeira foram ultrapassados" (CONTI, 2016, p. 154). Por sua vez, em artigo trazendo reflexão sobre a deficiência na gestão das finanças públicas pela flexibilização que se faz dentro dessa temática, cf. FERREIRA; OLIVEIRA, 2017. 
Para quem gasta mal, nenhum recurso será suficiente. A questão desafia não só o montante da dívida para respeito formal à norma, mas, sobretudo, a sua qualidade. É o que se aprofunda em arremate.

\section{DÍVIDA PÚBLICA E REGRA DE OURO: A VEDAÇÃO AO RETROCESSO}

Ao perscrutar os meandros da dívida, é preciso reconhecer preliminarmente que, embora se tenha superado o equilíbrio rígido orçamentário de outrora ${ }^{52}$, tal baliza regulatória se ressignificou, incorporando-se à atual noção do endividamento sustentável ${ }^{53}$. Os excessos, então, devem ser extirpados: ao tempo em que descabe a ideia do equilíbrio matemático das contas públicas, sendo perfeitamente admissível o déficit, isso em nada altera o dever de responsabilidade fiscal, o que pressupõe a convivência com padrões limitativos precisos da dívida, evidência que se extrai de análise sistêmica do ordenamento pátrio. Destarte, a noção de equilíbrio das contas revalida-se contemporaneamente, deixando a ultrapassada ideia de vedação ao déficit e equilíbrio estanque entre receitas e despesas, para a aceitação atual do endividamento, associado a instrumentos que garantam o seu controle. Bem ou mal, a Regra de Ouro é norma criada com o intuito originário de levar a contento tal mister, embora venha se mostrando bastante ineficaz da forma como concebida na sistemática brasileira. Na prática, não gera o resultado a que se propõe. Ao revés, apesar da sua inclusão no ordenamento pátrio, o que se observa é o crescente endividamento e altos níveis de déficits correntes.

52 "Este principio, que es fundamental em las Finanzas clásicas, há sido negado por las Finanzas modernas no sólo em su realización práctica sino también em sus bases teóricas" (JARACH, 2003, p. 89). Complementa Gilberto Bercovici no Brasil: "A Constituição não contempla o princípio da equilíbrio orçamentário. (...) A implementação de políticas públicas exige, às vezes, a contenção de despesas, outras vezes gera déficits orçamentários” (BERCOVICI, 2003, p. 209). $\mathrm{O}$ autor, junto com Luis Massoneto, critica o controle rígido que esteriliza a capacidade de intervenção do Estado: "A implementação da ordem econômica e da ordem social da Constituição de 1988 ficaram restritas, assim, às sobras orçamentárias e financeiras do Estado. A constituição financeira de 1988 foi, deste modo, 'blindada'.” (BERCOVICI; MASSONETTO, 2006, 72).

53 Weder de Oliveira chama de endividamento sustentável o princípio do equilíbrio orçamentário moderno, com natureza dinâmica e intertemporal, adstrito à noção de sustentabilidade da dívida (OLIVEIRA, 2015, p. 379). Por sua vez, Fernando Scaff insere a conceito com base na ideia do "financeiramente sustentável": "Para que ocorra sustentabilidade financeira é necessário que seja estabelecido um período de tempo de médio e longo prazo, e que todos os elementos financeiros que estejam à disposição daquele ente público sejam analisados de forma conjunta, podendo mesmo haver déficits públicos periódicos visando alcançar certas metas sociais, e obter o necessário equilíbrio orçamentário, dentro do período de tempo estabelecido" (SCAFF, 2014, p. 40). 
Revelando-se inábil à contenção da dívida e tendo em vista projeções negativas para o seu cumprimento, a solução estaria na redução dos limites nela estabelecidos? De outro modo: flexibilizar, sem tratar sobre a qualidade da dívida, o que já se mostra fragilizado?

Não há dúvidas de que hoje se busca uma nova cultura de gestão pública, baseada no planejamento, na transparência e no controle das contas, valores que passam a integrar o eixo central da atividade financeira estatal, e, por óbvio, resultam invariavelmente na imposição de limites para o endividamento público. Conquanto não haja a expressa previsão de observância do equilíbrio orçamentário a partir do texto da Constituição de 1988, sua ausência literal não autoriza práticas deletérias, reveladoras de gestões ineficientes decorrentes de endividamentos desordenados. É inconcebível, pois, cogitar em uma política financeira que não se coadune ao rigor constitucional do uso responsável dos recursos do povo. Não há mais espaço para a ideologia da inesgotabilidade dos recursos, tampouco se admite a sua sangria indiscriminada ou aplicação fora do contexto de ética e justiça orçamentária, critérios que atualmente devem marcar a atuação estatal no âmbito das finanças públicas, de sorte que o equilíbrio das contas, se não mais é rígido e estanque, torna-se um desafio renovado no plano do financeiramente sustentável, pressuposto insuperável da administração pública contemporânea, em especial ao se notar a evolução das finanças do Estado e a sua relação com os direitos fundamentais e o princípio democrático, valores que rechaçam a sangria ineficiente dos recursos públicos ${ }^{54}$.

Nesse enfoque é que deve se inserir também a disciplina da dívida pública, daí por que os instrumentos de controle devem primar não só pelo respeito aos limites formais de endividamento, mas, sobretudo, pela aderência aos preceitos que a fundamentam. É exatamente por isso que, muito mais do que a rolagem do problema pela simples flexibilização da Regra de Ouro, a solução para a baixa margem de seu cumprimento envolve medidas estruturantes. Se a norma, tal como posta nos termos do art. 167, III da CF/88, já se mostrou insuficiente para inibir o aumento do déficit público, de que adianta relativizá-la mais ainda sem que tal medida esteja acompanhada do tratamento no longo prazo da qualidade da dívida? Ao contrário, é momento de continuar a perseverar rumo ao recrudescimento da cultura de responsabilidade fiscal ${ }^{55}$. Não se quer retroceder para anos

${ }^{54}$ Em artigo que aborda a missão das finanças estatais no Estado constitucional e o papel do orçamento público na efetiva tutela dos direitos fundamentais e na consolidação da democracia, cf. FERREIRA, 2018b.

55 Licurgo Mourão lembra que hoje se colhe os louros de uma política de estabilização com base na trajetória de responsabilização fiscal, sendo o momento propício para a sua consolidação: 
sombrios de descontrole das finanças públicas, se é que eles já passaram. É óbvio, portanto, que o aprimoramento da Regra de Ouro passa por soluções que vão muito além da sua perfunctória mitigação.

A verdade é que a dívida pública, em si, não é o problema. Em essência, é instituto capaz de gerar frutos benéficos. Isso vai depender, contudo, da qualidade na sua aplicação. Há despesas públicas produtivas e improdutivas que podem ser originadas a partir da dívida. O que se deseja é o desembolso que traga resultados benéficos concretos. Nesse enfoque, um limite estreito para uma dívida de péssima qualidade não é melhor do que outro mais largo em que se assegurem premissas de eficiência. A avaliação dos limites da dívida é relativa e passa, inevitavelmente, pela análise de sua qualidade: gerar dívida para quê? Ou ainda: flexibilizar seus limites para quê? No fundo, não existem soluções mágicas para situações que se mostram complexas, e que nem a lei fria, mesmo com limites rígidos ao endividamento, pode ser capaz de fechar as brechas e resolver algo que se situa, muito mais, na atuação comprometida dos agentes que fazem uso dos recursos do povo. O dinheiro que sai do seu verdadeiro titular, não se esqueça, deve para ele retornar por meio dos serviços e investimentos sociais. Não se trata de faculdade estatal, mas dever que se impõe. É hora, pois, de prosseguir avançando para corrigir equívocos e tratar de forma responsável o endividamento público, em vez de reduzir limites e tolerar gastos perdulários sem planejamento a longo prazo.

Sem prejuízo de medidas emergenciais para reverter a projeção negativa da margem de cumprimento da Regra de Ouro para os exercícios vindouros ${ }^{56}$, alte-

\footnotetext{
"Entretanto, a grande missão que perdura é a adoção de medidas complementares e a adoção de práticas que ponham por terra qualquer iniciativa tendente a descontruir esse patamar do desenvolvimento a duras penas conquistado" (MOURÃO, 2010, p. 234). Por sua vez, Weder de Oliveira afirma: "Hoje há uma "consciência da responsabilidade fiscal" germinando na administração pública, em todos os níveis e em todos os Poderes, e também na sociedade. E podemos entendê-la como a consciência da necessidade de, simultaneamente, valorizar as receitas públicas, adequar os gastos às possibilidades de ingresso de recursos e conter o endividamento a um nível que não inviabilize a capacidade do Estado de cumprir suas funções constitucionais e honrar seus compromissos financeiros, com seus servidores, fornecedores e financiadores" (OLIVEIRA, 2010, p. 446-447).

56 Dentre outras, é o que se tem observado com medidas imediatas de cancelamento de restos a pagar, utilização de recursos do Fundo Soberano do Brasil e do Fundo Nacional de Desenvolvimento, desvinculação de fontes orçamentárias de superávits de exercícios anteriores, devolução de recursos por parte do BNDES e, ainda, a perspectiva de operações de créditos superiores às despesas de capital autorizadas nos termos do art. 167, III, CF/88. No ponto, posiciona-se Antonio Carlos Costa d’Ávila contra o mecanismo de operações de crédito condicionadas inse-
} 
rações que se idealizem para tal norma invocam soluções que propiciem o zelo pela qualidade da dívida, do contrário, seja qual for o seu limite, não se concretizarão as funções para as quais é chamada a exercer, além de ser insustentável lançar mão de válvulas de escape indefinidamente. E, obviamente, a redução dos limites da Regra de Ouro ou sua simples flexibilização seria só mais uma dessas saídas protelatórias que não enfrentam a questão de fundo. A própria ideia de transformá-la em cláusula plurianual, como se costuma conjecturar, postergando o prazo para avaliação do seu cumprimento, embora seja medida simpática à primeira vista, verdadeiramente também não ataca a questão de frente. Vale recordar que a Regra de Ouro, no modelo brasileiro, como já dito, é por demais aberta e deslocada da acepção clássica, de modo que sua previsão já não traz garantia de endividamento sustentável, porquanto não restringe as operações de crédito aos investimentos (o fator limitativo engloba todas as despesas de capital), tampouco cria impedimento à sua aplicação no financiamento de despesas correntes (o que sugere a leitura apressada da norma constitucional), minguando a regra na sistemática nacional.

Nesse panorama em que a Regra de Ouro não se liga necessariamente à qualidade do endividamento, torna-se arriscado maximizar o risco procrastinando o descontrole da dívida considerando limitação dilatada plurianual. Embora a estabilidade das contas revele-se como valor mensurável de forma dinâmica, exame que ultrapassa um singelo exercício financeiro, a dimensão da sustentabilidade obriga também e principalmente a avaliação qualitativa dos compromissos intergeracionais assumidos, de modo que não se dissociam os conceitos de plurianualidade e qualidade do endividamento. Não garantido esse último, o primeiro fica afetado. Tudo passa pela reafirmação da qualidade da dívida. Se não há melhor configuração de controle da qualidade da dívida pela Regra de Ouro, a evidência de sua atual deterioração conduz à prudência na adoção de parâmetro temporal anual para que se evitem montantes elevados que fujam ao controle estatal. Medida diversa pode criar a falsa sensação de domínio dentro de um espectro de proteção ilusório que, adiante, venha causar prejuízo irreparável.

ridas já no PLOA 2019, mas nada impediria o envio paralelo de projeto de lei específico para ressalvar a regra de ouro, ao final concluindo que: “(i) o total das despesas constantes do Projeto de Lei Orçamentária Anual referente ao exercício financeiro de 2019 (PLOA2019) a ser encaminhado ao Congresso Nacional pelo Chefe do Poder Executivo não pode ser superior ao total das fontes de financiamento viáveis e possíveis para referido exercício; e (ii) é compatível com o ordenamento jurídico em vigor, por se tratar de situação excepcionalíssima prevista pela própria Constituição da República, o encaminhamento ao Congresso Nacional, em paralelo à apreciação do PLOA2019, do Projeto de Lei de Crédito Adicional (especial ou suplementar) destinado a ressalvar a 'regra de ouro'." (CARVALHO JUNIOR, 2018, p. 14). 
Não só é preciso evitar o retrocesso com o abrandamento de uma regra já fragilizada, mas, sobretudo avançar no aperfeiçoamento da referida cláusula, harmonizando a Regra de Ouro ao conjunto de medidas que garantam o seu objetivo, cujo formato atual se afasta profundamente das premissas que relacionam a dívida à sua verdadeira função $0^{57}$. Os desafios que se apresentam ao aprimoramento da disciplina dessa relevante norma constitucional dizem respeito, sobretudo, à reavaliação quanto ao ampliado conceito das despesas de capital para fins de limite das operações de crédito, o alto volume de receitas financeiras de fontes diversas consideradas em seu cômputo e a falta de blindagem às operações de crédito financiadoras de despesas correntes. É claro que as providências para enfrentar o problema da dívida pública não se encerram apenas no aperfeiçoamento da Regra de Ouro, envolvendo diversas outras variáveis que fogem ao escopo deste ensaio, mas é preciso a compreensão de que a análise não está limitada ao montante do endividamento, pelo que a baixa margem para atendimento da Regra de Ouro passa, invariavelmente, pela qualidade da dívida.

\section{CONSIDERAÇÕES FINAIS}

A dívida pública pode assumir diferentes feições, dependendo da sua aplicação e dos limites para utilização: trata-se de instrumento benéfico propulsor de incremento patrimonial ou se transforma em mecanismo nocivo de desequilíbrio fiscal e injustiça intergeracional. O que separa essa tênue linha divisória é a qualidade da destinação dos recursos e o respeito às premissas que asseguram a contemporânea noção de endividamento sustentável. Em outros termos, a dívida pública não é propriamente um mal; ao contrário, pode ser potencialmente benfazeja. Inevitavelmente, portanto, qualquer análise responsável que se proceda em rela-

57 Tudo vai depender da qualidade da dívida: "Especialistas destacam a importante função que o endividamento público exerce ao garantir níveis equilibrados de investimento e serviços prestados pelo governo à sociedade, propiciando maior equidade entre gerações. As receitas e as despesas de um governo passam por ciclos e sofrem choques frequentes. $\mathrm{Na}$ ausência do crédito público, estes teriam de ser absorvidos por aumentos inesperados nos impostos do governo ou em cortes excessivos de gastos, penalizando, demasiadamente, em ambos os casos, a geração atual. Além da suavização intertemporal do padrão de serviços à sociedade, o acesso ao endividamento público permite atender a despesas emergenciais e assegurar o financiamento tempestivo de grandes projetos com horizonte de retorno no médio e no longo prazos. (...). O endividamento público pode exercer funções ainda mais amplas para o bom funcionamento da economia, auxiliando a condução da política monetária e favorecendo a consolidação do sistema financeiro. A lição fundamental dessa discussão recai na relevância de se zelar pela qualidade do crédito público. Só assim se pode valer do endividamento e de suas funções de forma eficiente" (SILVA; CARVALHO; MEDEIROS, 2009, p. 17). 
ção ao tema de fundo não se pode restringir a uma questão pontualmente numérica. Embora seja forçoso o discernimento acerca da esgotabilidade dos recursos, a avaliação pressupõe antes o ingresso na identificação dos gastos que compõem os encargos assumidos pela via da dívida, porquanto da qualidade desses compromissos decorre também a sua viabilidade.

O controle do endividamento público, assim, alcança vital importância na medida em que se torna elemento prejudicial à própria preservação das funções precípuas da dívida. Nesse sentido, norma que se presta a contribuir nesse desiderato é a Regra de Ouro estatuída no art. 167, III da CF/88, cuja configuração, todavia, desvia-se consideravelmente daquela percebida em sua versão clássica. Se a referida cláusula, em origem, busca criar uma barreira para evitar que recursos oriundos de operações de crédito superem as despesas de capital, bloqueando, por esse meio, o financiamento de despesas sem aptidão para incremento patrimonial, na prática, porém, não é isso que se vivencia na experiência brasileira. Seja pelo conceito ampliado das despesas de capital, bem como pelo alto índice de receitas financeiras de fontes diversas, ou ainda, pela ausência de efetiva blindagem de operações de crédito aplicadas na cobertura de gastos correntes, tem-se a convivência do respeito formal da regra constitucional com déficits crescentes e a alarmante redução da margem para seu cumprimento nos próximos anos.

A realidade mostra que a Regra de Ouro brasileira não vem assegurando, por conta própria, a sustentabilidade da dívida pública. E nem poderia, pois a norma, além de afastada dos princípios basilares que deveriam norteá-la, verdadeiramente não é capaz de solucionar um problema cuja raiz se apresenta muito mais no dever de comprometimento responsável dos agentes investidos da gestão dos recursos do povo. Pior ainda, contudo, é admitir a rasa argumentação em favor da atenuação de uma norma já fragilizada, sem que seja acompanhada de medidas alternativas que se dirijam à sustentabilidade e qualidade da dívida. A questão se liga a desafios estruturantes, não bastando a rolagem do problema com a mera flexibilização da Regra de Ouro. A questão não é apenas a quantidade da dívida, mas a sua qualidade.

\section{REFERÊNCIAS}

ABRAHAM, Marcus. Curso de direito financeiro brasileiro. 4. ed. Rio de Janeiro: Forense, 2017a.

ABRAHAM, Marcus. Lei de responsabilidade fiscal comentada. 2. ed. Rio de Janeiro: Forense, 2017b.

ALMEIDA, Dayson Pereira Bezerra de; BIJOS, Paulo Roberto Simão. Cumprimento de meta fiscal versus equilíbrio das contas públicas. Estudo Técnico n. 9/2018.

Consultoria de Orçamentos e Fiscalização Financeira. Brasília: Câmara dos Deputados, 2018. 
ASSONI FILHO, Sérgio. Crédito público e responsabilidade fiscal. Porto Alegre: Nuria Fabris, 2007.

ATALIBA, Geraldo. Empréstimos públicos e seu regime jurídico. São Paulo: Revista dos Tribunais, 1973.

BALEEIRO, Aliomar. Uma introdução à ciência das finanças. 15. ed. Rio de Janeiro: Forense, 1997.

BERCOVICI, Gilberto. Desigualdades regionais, Estado e Constituição. São Paulo: Max Limonad, 2003.

BERCOVICI, Gilberto; MASSONETTO, Luís Fernando. A Constituição dirigente invertida: a blindagem da Constituição financeira e a agonia da Constituição económica. Universidade de Coimbra. Boletim Ciências Económicas, v. XLIX, p. 57-77, 2006.

BONAVIDES, Paulo. Do estado liberal ao estado social. São Paulo: Malheiros, 2013.

BOUÇAS, Valentim F. História da dívida externa. 2. ed. Rio de Janeiro: Ed.

Financeiras, 1950.

BRASIL. Ministério da Fazenda. Secretaria do Tesouro Nacional. Informe Dívida

- Projeções para a Regra de Ouro. Coordenação-Geral de Planejamento Estratégico da

Dívida Pública - COGEP. Brasília: Tesouro Nacional, 2018.

BRASIL. Câmara dos Deputados. Consultoria de Orçamento e Fiscalização Financeira; Senado Federal. Consultoria de Orçamentos, Fiscalização e Controle. Subsídios à apreciação do projeto de Lei de Diretrizes Orçamentárias para 2019. Nota Técnica Conjunta ${ }^{\circ}$ 1/2018. Brasília: Congresso Nacional, 2018.

BUCHANAN, James M. The limits of liberty: between anarchy and Leviathan. Chicago: The University of Chicago Press, 1975.

CANOTILHO, José Joaquim Gomes. Direito constitucional e teoria da constituição. 7. ed. Coimbra: Almedina, 2003.

CARVAlHO JUNIOR, Antonio Carlos Costa d'Ávila et al. Regra de Ouro na Constituição e na LRF: considerações históricas e doutrinárias. Estudo Técnico Conjunto n. 2/2017. Consultoria de Orçamentos e Fiscalização Financeira; Consultoria de Orçamentos, Fiscalização e Controle. Brasília: Senado Federal; Câmara dos Deputados, 2017.

CARVAlHO JUNIOR, Antonio Carlos Costa d'Ávila. A “Regra de Ouro” e o Orçamento de Investimentos (OI). Estudo Técnico n. 2/2018. Consultoria de Orçamentos e Fiscalização Financeira. Brasília: Câmara dos Deputados, 2018.

CARVAlHO JUNIOR, Antonio Carlos Costa d'Ávila. Receitas e Despesas Condicionadas versus "Regra de Ouro". Estudo Técnico n. 3/2018. Consultoria de Orçamentos, Fiscalização e Controle. Brasília: Câmara dos Deputados, 2018. CARVALHO JUNIOR, Antonio Carlos Costa d'Ávila. Processo Legislativo Orçamentário e a "Regra de Ouro". Estudo Técnico n. 1/2018. Consultoria de Orçamento e Fiscalização Financeira. Brasília: Câmara dos Deputados, 2018. 
CATARINO, João Ricardo. Finanças públicas e direito financeiro. Coimbra: Almedina, 2012.

CHICOLI, Raí da Silva; BENDER, Siegfried. Sustentabilidade da dívida pública brasileira: uma análise sob diversos conceitos de superávit primário e endividamento. Department of Economics - FEA/USP, Working Paper Series, n. 37, 2015.

CONTI, José Mauricio. Levando o direito financeiro a sério: a luta continua. 2. ed. São Paulo: Blucher, 2018.

CONTI, José Mauricio. Comentários aos arts. 32 a 39 da Lei de Responsabilidade Fiscal. In: MARTINS, Ives Gandra da Silva; NASCIMENTO, Carlos Valder do Nascimento (org.). Comentários à lei de responsabilidade fiscal. 2. ed. São Paulo: Saraiva, 2007.

COURI, Daniel Veloso; SALTO, Felipe Scudeler; BARROS, Gabriel Leal de; ORAIR, Rodrigo Octávio. Regra de ouro no Brasil: balanços e desafios. Estudo Especial n. 5/2018. Instituição Fiscal Independente (IFI). Brasília: Senado Federal, 2018.

EINAUDI, Luigi. Principios de hacienda publica. Tradução de J. Alcarra e Miguel Paredes. Madrid: Aguillar, 1948.

FERREIRA, Francisco Gilney Bezerra de Carvalho. Orçamento público e separação de poderes no estado constitucional democrático brasileiro. Rio de Janeiro: Lumen Juris, 2018.

FERREIRA, Francisco Gilney Bezerra de Carvalho. A missão constitucional do orçamento público na efetiva tutela dos direitos fundamentais e na consolidação da democracia. Revista General de Derecho Constitucional (IUSTEL), v. 27, 2018.

FERREIRA, Francisco Gilney Bezerra de Carvalho; OLIVEIRA, Claudio Ladeira. O orçamento público no Estado constitucional democrático e a deficiência crônica na gestão das finanças públicas no Brasil. Revista Sequência, v. 38, n. 76, p. 183-212, 2017. FONROUGE, Carlos M. Giuliani. Derecho financiero. 10. ed. Buenos Aires: La Ley, 2011. v. 2.

FREITAS, Juarez. O direito fundamental à boa administração pública. São Paulo: Malheiros, 2014.

GAMBIAGI, Fábio. À procura de um consenso fiscal: o que podemos aprender da experiência internacional? Revista do BNDES, v. 8, n. 15, p. 65-102, 2001.

GIACOMONI, James. Orçamento público. 17. ed. São Paulo: Atlas, 2017.

HARADA. Kiyoshi. Direito financeiro e tributário. 7. ed. São Paulo: Atlas, 1995.

JARACH, Dino. Finanzas públicas y derecho tributario. 3. ed. Buenos Aires: AbeledoPerrot, 2003.

KEYNES, John Maynard. The general theory of employment, interest and money. London: Macmillan, 1951.

LAPATZA, José Juan Ferreiro. Instituciones de derecho financiero. Madrid: Marcial Pons, 2010. 
MENDONÇA, Félix et al. A divida pública brasileira. Cadernos de Altos Estudos n. 2. Conselho de Altos Estudos e Avaliação Tecnológica. Brasília: Câmara dos Deputados, 2005.

MOURÃO, Licurgo. Dez anos de gestão fiscal responsável: experiências para a efetividade do controle governamental como instrumento de responsabilidade fiscal. In: CASTRO, Rodrigo Pironti Aguirre de (org.). Lei de responsabilidade fiscal: ensaios em comemoração aos 10 anos da Lei Complementar n. 101/00. Belo Horizonte: Fórum, 2010.

NASCIMENTO, Edson Ronaldo; DEBUS, Ivo. Entendendo a lei de responsabilidade fiscal. 2. ed. Brasília: Secretaria do Tesouro Nacional, 2002.

OLIVEIRA, Regis Fernandes de. Curso de direito financeiro. 7. ed. São Paulo: Revista dos Tribunais, 2015.

OLIVEIRA, Weder de. Curso de responsabilidade fiscal: direito, orçamento e finanças públicas. Belo Horizonte: Fórum, 2015.

PELLEGRINI, Josué Alfredo. Dívida pública brasileira: mensuração, composição, evolução e sustentabilidade. Textos para Discussão n. 226. Núcleo de Estudos e Pesquisas da Consultoria Legislativa. Brasília: Senado Federal, 2017.

PIRES, Manoel. Uma análise da regra de ouro no Brasil. Observatório de Política Fiscal. Instituto Brasileiro de Economia (IBRE). Rio de Janeiro: FGV, 2018.

RAWLS, John. Uma teoria da justiça. Tradução de Almiro Pisetta e Lenita M. R. Esteves. São Paulo: Martins Fontes, 1997.

RIBEIRO, José Joaquim Teixeira. Lições de finanças públicas. 5. ed. Coimbra: Editora Coimbra, 1997.

SCAFF, Fernando Facury. Crônicas de direito financeiro: tributação, guerra fiscal e políticas públicas. São Paulo: Editora Conjur, 2016.

SCAFF, Fernando Facury. Crédito público e sustentabilidade financeira. Revista Direito à Sustentebilidade, v. 1, n. 1, p. 34-47, 2014.

SCAFF, Fernando Facury; ATHIAS, Daniel Tobias. Dívida pública e desenvolvimento: do equilíbrio orçamentário à sustentabilidade financeira. Revista Científica Fagoc Jurídica, v. I, p. 85-96, 2016.

SILVA, Anderson Caputo; CARVALHO, Lena Oliveira; MEDEIROS, Otavio Ladeira (org.). Dívida pública: a experiência brasileira. Secretaria do Tesouro Nacional: Banco Mundial, 2009.

TORRES, Heleno Taveira. Direito constitucional financeiro: teoria da constituição financeira. São Paulo: Revista dos Tribunais, 2014.

TORRES, Ricardo Lobo. Tratado de direito constitucional financeiro e tributário: orçamento na Constituição. 3. ed. Rio de Janeiro: Renovar, 2008. v. 5.

VILLEGAS, Héctor B. Curso de finanzas, derecho financiero y tributario. 7. ed. Buenos Aires: Depalma, 2001. 